\title{
MODEL PENGINTEGRASIAN SPENDING REVIEW DALAM PENGAMBILAN KEPUTUSAN ANGGARAN PADA KEMENTERIAN KESEHATAN REPUBLIK INDONESIA
}

\author{
Beni Ruslandi ${ }^{1}$, Bahrullah Akbar ${ }^{2}$, Aries Djaenuri ${ }^{3}$, Deti Mulyati ${ }^{4}$ \\ 1,2,3,4 Institut Pemerintahan Dalam Negeri (IPDN) \\ Email: b.ruslandi@gmail.com
}

\begin{abstract}
Abstrak
Pengambilan keputusan anggaran pada Kementerian Kesehatan belum memanfaatkan hasil spending review yang dilakukan oleh Kementerian Keuangan. Kondisi tersebut diindikasikan oleh masih terdapat tujuh indikator RPJMN Kesehatan yang belum tercapai dan masih memerlukan kerja keras meskipun realisasi belanja kesehatan terus meningkat.Oleh karena itu fokus penelitian ini bertujuan untuk mengeksplorasi model pengintegrasian spending review dalam pengambilan keputusan anggaran pada Kementerian Kesehatan. Penelitian ini menggunakan pendekatan kualitatif dengan metoda eksploratif, dimana peneliti berupaya untuk mengeksplorasi dan membangun fenomena yang diteliti dalam upaya menjawab masalah yang dirumuskan sebelumnya. Hasil dari penelitian menunjukkan ada faktor-faktor yang menghambat dan mendukung integrasi spending review dalam pengambilan keputusan anggaran pada Kementerian Kesehatan sehingga diperlukan strategi yang tepat dalam pengintegrasian spending review tersebut.
\end{abstract}

Kata Kunci: Pengintegrasian, Spending Review, Anggaran, Efisiensi.

\begin{abstract}
Budget decision making at the Ministry of Health has not taken advantage of the results of the spending review conducted by the Ministry of Finance. This condition is indicated by there are still seven indicators of RPJMN Health that have not been achieved and still require hard work even though the realization of health spending continues to increase. Therefore, the focus of this study aims to explore a model of integrating spending review in budget decision making at the Ministry of Health. This study uses a qualitative approach with an exploratory method, where the researcher seeks to explore and build the phenomena under study in an effort to answer the problems formulated previously. The results of the study indicate that there are factors that hinder and support the integration of spending reviews in budget decision making at the Ministry of Health so that an appropriate strategy is needed in integrating the spending review.
\end{abstract}

Keywords: Integration, Spending Review, Budget, Efficiency.

\section{A. PENDAHULUAN}

Masalah anggaran sering digambarkan sebagai masalah ekonomi yang mendasar dalam mengalokasikan sumber daya yang langka ke tujuan alternatif untuk memaksimalkan manfaat yang diterima dari program dan layanan yang didanai oleh anggaran. Hal ini terlihat dari efisiensi teknis dan ekonomis yang sangat dipegang teguh dalam proses anggaran eksekutif, dan penghematan merupakan salah satu fungsi utamanya (Rutgers \& Van Der 
Meer, 2010). Memperkuat kekuatan dan pengaruh pengambilan keputusan ekonomi dalam proses anggaran telah menjadi salah satu tujuan terpenting dari berbagai reformasi anggaran. Akan tetapi, anggaran lebih dari sekedar proses pengambilan keputusan ekonomi. Anggaran juga merupakan dokumen kebijakan utama pemerintah dan masalah kebijakan publik yang melibatkan lebih dari nilai efisiensi. Kebijakan yang efektif menuntut lebih dari pertimbangan ekonomi. Kebijakan publik juga membahas masalah sosial, hukum, dan politik.

Setiap aspek masalah anggaran berkaitan dengan sosial, politik, hukum, ekonomi, dan secara teknis dapat dianggap sebagai jenis masalah yang terpisah (Catalano \& Erbacci, 2018). Karena masalah ekonomi memerlukan keputusan ekonomi, maka masalah sosial memerlukan keputusan sosial, masalah politik memerlukan keputusan politik, dan sebagainya (Melkers \& Willoughby, 2018). Argumen ini memberikan gambaran terhadap pandangan komprehensif tentang masalah anggaran yang memerlukan analisis komprehensif dan pertimbangan banyak alternatif kebijakan serta efisiensi.

Tidak dapat dipungkiri bahwa sifat alami dari masalah ekonomi dan pengambilan keputusan ekonomi, dikombinasikan dengan waktu yang terbatas pada fase perumusan, mengharuskan penyusun anggaran untuk mengatasi masalah non-ekonomi pada periode sebelum tahap perumusan yaitu, dalam fase pelaksanaan anggaran (Simon, 1959). Dari lima jenis keputusan non-ekonomi, yang paling dinamis dan sangat terlihat adalah keputusan politik, yang merupakan fokus utama dari model pilihan politik-inkremental (Thurmaier \& Willoughby, 2001).

Struktur pengambilan keputusan politik dirancang untuk memungkinkan pembuat keputusan mendengarkan beragam sudut pandang mengenai perbedaan nilai di sekitar nilainilai inti masyarakat (Thumaier, 1995a). Fischer memberi nama hal ini sebagai nilai periferal dan masalah yang timbul dari perbedaan ini adalah subyek perdebatan dalam proses politik (Fischer, 2003). Struktur pengambilan keputusan politik yang efektif menyeimbangkan kebutuhan dari beragam sudut pandang untuk diwakili dalam debat sosial dan kebutuhan untuk mencapai beberapa keputusan setelah debat (Irvin \& Stansbury, 2004). Keputusan politik yang efektif dapat mengungkapkan penilaian sosial yang bersifat tidak mutlak dari program pemerintah.

Pada dasarnya, penyusun anggaran menggunakan tahap pelaksanaan untuk membahas berbagai permasalahan non ekonomi dalam rangka mengidentifikasi dan menyusun alternatif pengalokasian sumber daya (Thumaier, 1992). Kemudian ketika tahap perumusan anggaran sampai pada tahap yang semakin intensif, penyusun anggaran dapat berkonsentrasi pada permasalahan ekonomi. Sehingga, penyusun anggaran tidak perlu bergantung pada 
serangkaian proses pengambilan keputusan yang disederhanakan untuk mengelola kompleksitas yang melekat dalam analisis komprehensif permasalahan anggaran. Penyusun anggaran harus memanfaatkan siklus anggaran secara penuh untuk menganalisis berbagai segi dan menggabungkan analisis dari setiap segi tersebut menjadi rekomendasi anggaran kepada pimpinan/pemerintah.

Penyusun anggaran melakukan berbagai analisis berdasarkan rasionalitas dan hal-hal lainnya. Penyusun anggaran harus membahas kelima rasionalitas yang melekat dalam permasalahan anggaran khususnya dimensi politik, ekonomi, dan teknis (Thumaier, 1992). Penyusun anggaran berasumsi bahwa dimensi politik mencerminkan nilai-nilai yang dihasilkan oleh keputusan sosial, dan dimensi ekonomi menghasilkan cara yang efisien secara teknis. Mereka kemudian menyusun rekomendasi dengan memberikan bobot pada dimensi ekonomi dan politik.

APBN (Anggaran Pendapatan dan Belanja Negara) merupakan alat kebijakan fiskal yang sangat penting untuk mencapai tujuan berbangsa dan bernegara serta mewujudkan kesejahteraan rakyat. Undang-undang No. 17 tahun 2003 tentang keuangan negara pasal 3 ayat (1) menetapkan bahwa "keuangan negara dikelola secara tertib, taat pada peraturan perundang-undangan, efisien, ekonomis, efektif, transparan, dan bertanggung jawab dengan memperhatikan rasa keadilan dan kepatutan". Sehubungan dengan ketentuan tersebut, maka pelaksanaan anggaran harus efektif, efisien dan akuntabel sehingga anggaran dapat mencapai kinerja secara optimal, sumber daya dapat digunakan sebaik-baiknya dan memenuhi prinsipprinsip tatakelola pemerintahan yang baik. Agar anggaran dapat mewujudkan kesejahteraan rakyat secara efektif dan efisien, maka anggaran tersebut harus dikelola dengan baik sejak tahap penyusunannya. Sehubungan dengan ketentuan tersebut, maka pelaksanaan anggaran harus efektif, efisien dan akuntabel sehingga anggaran dapat mencapai kinerja secara optimal, sumber daya dapat digunakan sebaik-baiknya dan memenuhi prinsip-prinsip tatakelola pemerintahan yang baik (Fadly, dkk., 2018). Agar anggaran dapat mewujudkan kesejahteraan rakyat secara efektif dan efisien, maka anggaran tersebut harus dikelola dengan baik sejak tahap penyusunannya.

Selama tahun 2013 sampai dengan tahun 2018, belanja pemerintah meningkat dari Rp 1.650,56 triliun menjadi Rp 2.220,66 triliun. Termasuk di dalam belanja tersebut adalah alokasi belanja wajib (mandatory) antara lain belanja kesehatan dan belanja Pendidikan. Peningkatan belanja tersebut tidak sebanding dengan peningkatan pendapatan sehingga menimbulkan defisit yang cenderung meningkat. Sehubungan dengan hal tersebut pemerintah perlu meningkatkan efisiensi dan optimalisasi belanja. Selain itu, terdapat permasalahan 
dalam anggaran dan pelaksanaannya. Permasalahan anggaran antara lain berupa belum kredibelnya anggaran yang dicerminkan oleh tidak tercapainya estimasi pendapatan dan target pengeluaran.

Sedangkan dalam pelaksanaan anggaran terdapat permasalahan penyerapan anggaran, pola penyerapan yang belum ideal dan efisiensi serta efektivitas belanja (Parhusip, 2016). Hasil spending review atas rencana belanja tahun 2018 ditemukan potensi inefisiensi belanja sebesar Rp. 2.425,81 milyar dan einmalig sebesar Rp. 9.392,57 milyar (Prabowo, 2018). Inefisiensi tersebut terjadi karena adanya belanja yang tidak diperlukan tetapi dianggarkan. Sedangkan einmalig merupakan kegiatan program yang telah selesai dilaksanakan di tahun sebelumnya sehingga tidak perlu lagi dianggarkan di tahun berikutnya tetapi kenyataannya masih dianggarkan.

Permasalahan inefisiensi tersebut menjadi sangat penting dalam belanja negara di tengah kecenderungan banyak negara khususnya negara-negara di Eropa dan Amerika Serikat untuk mengurangi belanja publik dan menerapkan kebijakan perampingan belanja sebagai dampak dari terjadinya krisis ekonomi global (Pollitt \& Bouckaert, 2017). Memburuknya kondisi keuangan publik pada banyak negara sebagai akibat krisis keuangan global mendorong meningkatnya minat terhadap metode stabilisasi fiskal dan konsolidasi yang inovatif (Robinson, 2003). Akan tetapi, sering kali, penyusunan anggaran lebih fokus pada proposal belanja baru dan kurang memperhatikan belanja yang telah dilakukan sebagai dasar (baseline).

Jika kondisi ini terjadi maka sumber daya yang langka akan terus terbuang untuk program yang sedang berjalan tetapi tidak efektif, memiliki prioritas rendah serta tidak bermanfaat (Robinson, 2003). Pendapat-pendapat tersebut menunjukkan pentingnya perbaikan dalam penyusunan anggaran belanja pemerintah, khususnya dalam proses pengambilan keputusan alokasi anggaran dengan mempertimbangkan evaluasi atas programprogram yang sedang berlangsung di samping menilai usulan program-program baru.

Salah satu kegiatan yang dilakukan untuk mengevaluasi anggaran dan pelaksanaannya adalah kegiatan spending review. Spending review merupakan alat untuk menerapkan reformasi keuangan, khususnya untuk meningkatkan ketersediaan celah fiskal melalui pemotongan dan realokasi anggaran (Hawkesworth \& Klepsyik, 2013). Di Indonesia, kegiatan spending review mulai dilaksanakan sejak tahun 2013 oleh Direktorat Jenderal Perbendaharaan Kementerian Keuangan. Fokus pelaksanaan spending review adalah efektivitas, efisiensi dan ekonomis atas penggunaan belanja sebagaimana tercantum pada 
Surat Edaran Dirjen Perbendaharaan No. 12/PB/2016 tentang Penyusunan spending review meliputi:

1. Mengidentifikasi potensi ruang fiskal yang dapat digunakan sebagai bahan perbaikan kebijakan Anggaran;

2. Mengukur kinerja belanja pemerintah baik dari aspek ekonomis dan/atau efisiensi dan/atau efektivitas;

3. Mengidentifikasi program/kegiatan yang hanya diperlukan satu kali sebagai peringatan dini agar tidak diulang/dilanjutkan pada tahun berikutnya;

4. Memberikan masukan/rekomendasi untuk merumuskan kebijakan Anggaran dan kebijakan pelaksanaan anggaran dalam rangka peningkatan kualitas belanja pemerintah;

5. Memberikan bahan masukan bagi penyusunan rencana kerja kementerian/lembaga.

Dengan demikian, hasil spending review sangat bermanfaat dalam merumuskan kebijakan anggaran tahun berikutnya karena spending review tidak hanya berkaitan dengan efisiensi dan efektivitas tetapi berkaitan juga dengan pengambilan keputusan dan tanggung jawab (Postula, 2017). Akan tetapi, hasil spending review di Indonesia belum benar-benar digunakan untuk pengambilan keputusan tahun anggaran berikutnya termasuk dalam keputusan pemotongan anggaran. Kondisi tersebut mengakibatkan pemerintah kesulitan untuk meningkatkan kualitas belanja (Parhusip, 2016).

Terdapat dua alasan pentingnya spending review harus menjadi bagian dari penyusunan anggaran. Pertama, dengan spending review maka analisa kebutuhan anggaran untuk program/kegiatan baru dan penghematan anggaran dapat dilakukan secara simultan, sehingga dapat ditentukan program/kegiatan baru yang memiliki prioritas tinggi serta pembiayaan program/kegiatan tersebut dilaksanakan tanpa meningkatkan belanja karena program/kegiatan tersebut didanai dari penghematan anggaran. Kedua, tingkat kedalaman spending review dapat dikalibrasi dalam konteks tujuan anggaran secara keseluruhan (Robinson, 2013).

Peneliti akan mengeksplorasi model pengintegrasian spending review dalan pengambilan keputusan anggaran pada Kementerian Kesehatan. Hal ini didasari kerena Kementerian Kesehatan belum memanfaatkan hasil spending review yang dilakukan oleh Kementerian Keuangan. Kondisi tersebut diindikasikan oleh masih terdapat tujuh indikator RPJMN Kesehatan yang belum tercapai dan masih memerlukan kerja keras meskipun realisasi belanja kesehatan terus meningkat. Selain itu, permasalahan-permasalahan yang ditemukan dalam spending review tahun 2017 masih terjadi dan ditemukan dalam spending 
review tahun 2018, bahkan untuk einmalig nilainya semakin meningkat dari sebesar $\mathrm{Rp}$ 180,54 milyar pada tahun 2017 meningkat menjadi sebesar Rp 427,20 milyar pada tahun 2018.

\section{B. METODE}

Penelitian ini menggunakan pendekatan kualitatif interpretif. Pendekatan kualitatif merupakan pendekatan empiris yang mengamati fenomena dalam konteks kehidupan nyata, terutama ketika batas antara fenomena dan konteksnya tidak dapat didefinisikan secara jelas (Yin, 2014). Pendekatan kualitatif dipilih karena penelitian ini dilakukan melalui proses menemukan, memahami, menjelaskan dan memperoleh gambaran tentang fenomena yang berhubungan dengan proses pengambilan keputusan anggaran pada Kementerian Kesehatan RI. Hakikat penelitian kualitatif adalah mengamati orang dalam lingkungan hidupnya berinteraksi dengan mereka, berusaha memahami bahasa dan tafsiran mereka tentang dunia sekitarnya, mendekati atau berinteraksi dengan orang-orang yang berhubungan dengan fokus penelitian dengan tujuan mencoba memahami, menggali pandangan dan pengalaman mereka untuk mendapat informasi atau data yang diperlukan (Cassel, dkk., 2017).

Penelitian ini bersifat eksploratif, di mana peneliti berupaya untuk mengeksplorasi dan membangun fenomena yang diteliti dalam upaya menjawab masalah yang dirumuskan sebelumnya. Penelitian eksplorasi bertujuan untuk mengeksplorasi secara luas penyebab atau hal-hal yang mempengaruhi terjadinya sesuatu. Pertimbangan peneliti untuk menggunakan pendekatan eksplorasi adalah bahwa fenomena yang dipelajari mencakup nilai-nilai, budaya, dan norma-norma dalam struktur organisasi atau faktor lain yang mendorong proses pengintegrasian dari spending review dalam pengambilan keputusan anggaran pada Kementerian Kesehatan.

Penelitian dengan pendekatan kualitatif, lebih menekankan pada pemberian makna (meanings) dan pemberian interpretasi terhadap obyek yang diteliti. Dengan demikian, penekanan terletak pada pemaknaan obyek masalah secara khusus. Dalam konteks penelitian ini, proses pemaknaan dan interpretasi dilakukan terhadap proses pengambilan keputusan anggaran pada Kementerian Kesehatan RI.

\section{HASIL DAN PEMBAHASAN}

APBN terus mengalami peningkatan dari tahun ke tahun. Hal tersebut sejalan dengan peningkatan kebutuhan pemerintah dalam memenuhi tujuan pembangunan sekaligus membiayai belanja wajib seperti belanja pendidikan, belanja kesehatan, belanja subsidi, dan 
beberapa belanja lain yang wajib dipenuhi. Dalam satu dekade terakhir, pemerintah gencar melaksanakan berbagai kegiatan untuk meningkatkan efektiftas dan efsiensi belanja. Presiden RI Joko Widodo secara khusus memperkenalkan model perencanaan money follows program, yaitu konsep dimana uang tidak lagi mengikuti fungsi/struktur organisasi tetapi uang mengikuti program/ kegiatan yang ingin dilakukan.

Pergeseran pendekatan pengelolaan belanja pemerintah dalam sistem Anggaran Pendapatan dan Belanja Negara (APBN) tersebut telah merubah pengukuran kinerja belanja yang sebelumnya diukur melalui persentase tingkat penyerapan anggaran menjadi tingkat efisiensi (ketercapaian output) serta efektivitas (ketercapaian dampak). Keterbatasan anggaran dan semakin ketatnya persaingan global menimbulnya kesadaran bagi pemerintah untuk meningkatkan performa perencanaannya dengan melakukan analisis lebih mendalam terhadap pelaksanaan belanja negara dengan kebutuhan yang benar-benar harus dilakukan untuk mensukseskan program pemerintah serta memperhitungkan nilai kemanfaatan yang dirasakan warga negara.

Pemerintah melakukan kebijakan penghematan belanja secara terus menerus dalam beberapa tahun terakhir. Optimalisasi penggunaan belanja pemerintah secara efektif, efisien, dan ekonomis atau mengoptimalkan implementasi prinsip value for money atas belanjanya terus dilakukan. Di sisi lain, adanya tuntutan publik terhadap pemerintah atas akuntabilitas pelaksanaan tugasnya turut mendorong semua pihak dalam melaksanakan efisiensi dan efektivitas belanja. Hal-hal tersebut mendorong Pemerintah Indonesia dalam hal ini Kementerian Keuangan melakukan spending review.

Pasal 8 PMK Nomor 195/PMK.05/2018 membagi spending review dalam dua kategori, yaitu umum dan tematik. Reviu belanja yang bersifat umum sebagaimana dilaksanakan pada awal tahun anggaran terhadap seluruh sektor atau K/L dalam mengidentifikasi potensi penghematan anggaran dan penyediaan ruang fiskal dalam Belanja K/L. Sementara itu, spending review tematik dilaksanakan secara insidentil dalam menindaklanjuti instruksi pimpinan atau isu/permasalahan khusus dan fokus pada suatu tema atau Kementerian/Lembaga tertentu.

Spending review adalah kegiatan penilaian orientasi strategis program dan/atau efisiensi belanja yang secara luas digunakan untuk memotong maupun mengalokasikan ulang anggaran belanja (Hawkesworth \& Klepsyik, 2013). Spending review sebagai proses pengadopsian dan pengembangan langkah-langkah penghematan berdasar pengawasan yang sistematis terhadap baseline anggaran belanja. Dalam hal ini, spending review digunakan sebagai alat kontrol tingkat pengeluaran agregat pemerintah dan untuk mempertajam 
penentuan prioritas belanja. Terdapat 3 (tiga) mekanisme atau pendekatan penyusunan spending review yang memiliki tujuan untuk melakukan analisa efisiensi dan efektivitas belanja yaitu (Robinson, 2013):

1. Reviu bawah-atas (Bottom-up review) yaitu reviu belanja dimana unit pelaksana kegiatan belanja mengembangkan pilihan penghematan mereka dengan pilihanpilihan yang telah disiapkan oleh unit pengelola keuangan.

2. Reviu bersama (Joint-review) yaitu reviu belanja dimana pilihan penghematan dikembangkan secara bersama oleh tim reviu unit pelaksana kegiatan dan unit pengelola keuangan.

3. Reviu atas-bawah (Top-down review) yaitu reviu belanja dimana pilihan penghematan dikembangkan oleh unit pengelola keuangan dengan keterlibatan unit pelaksana kegiatan yang terbatas.

Dari sudut pandang tipologinya, spending review dapat dibagi dua, yaitu:

1. Reviu efisiensi berfokus meningkatkan penghematan dengan memacu efisiensi anggaran, yaitu memberikan layanan dalam jumlah dan kualitas yang sama, tetapi dengan biaya serendahnya.

2. Reviu strategis dicapai dengan cara mengurangi layanan pemerintah beserta memotong besaran transfer payment.

Peraturan Menteri Keuangan Nomor PMK-195/PMK.05/2018 tentang Monitoring dan

Evaluasi Pelaksanaan Anggaran, pada Bab III mengenai Monitoring dan Evaluasi Pelaksanaan Anggaran Belanja Kementerian Negara/Lembaga Oleh Menteri Keuangan Selaku Bendahara Umum Negara, mengatur secara teknis pelaksanaan spending review. Tahapan kegiatan spending review tersebut dimulai dari pengumpulan data yang diperlukan dalam penyusunan spending review yang diatur dalam Pasal 9, yaitu:

1. Data capaian output;

3. Data realisasi anggaran;

4. Dokumen perencanaan dan penganggaran;

5. Dokumen pelaksanaan anggaran; dan

6. Data terkait lainnya yang relevan.

Spending review dilakukan dengan melaksanakan pemetaan, pengukuran yang menitikberatkan aspek efektif, efisien, dan ekonomis (value for money), serta penyusunan analisis menyeluruh dan strategis atas keluaran program dan kegiatan Belanja $\mathrm{K} / \mathrm{L}$. Pendekatan yang digunakan dalam spending review di Indonesia adalah: 
1. Reviu kebutuhan ideal belanja;

2. Analisa benchmarking;

3. Analisa deviasi kebutuhan belanja operasional, dan einmalig; dan

4. Pendekatan reviu lainnya.

Kegiatan spending review merupakan rangkaian dari pengaturan aktivitas monev anggaran, untuk melakukan analisa efisiensi, efektivitas dan nilai ekonomis belanja pada Kementerian/Lembaga sebagai bahan pertimbangan pengalokasian anggaran pada Direktorat Jenderal Anggaran. Catalano dan Erbacci (2008), menyarankan kerangka teoritis spending review dan mengidentifikasi empat dimensi dalam pelaksanaan spending review jangka menengah yaitu dimensi politik, sosial, organisasi dan proses serta elemen lintas yang bersifat dinamis yaitu waktu.

Berdasarkan hasil penelitian, diketahui faktor-faktor yang mempengaruhi pelaksanaan spending review. Faktor-faktor tersebut adalah pertama faktor sosial yang berupa peran dan dukungan lembaga Non Government Organization (NGO), lembaga internasioanl dan dukungan publik, Kedua, faktor organisasi yang mempengaruhi antara lain berupa dukungan Kementerian Keuangan, Sumber Daya Manusia baik di DJPb maupun di K/L, koordinasi antar institusi, transformasi kelembagaan, standard operating procedure (SOP), kualitas data serta proses transfer pengetahuan. Ketiga, faktor konseptual menyangkut kesesuaian antara metodologi yang digunakan dengan proses perencanaan dan penganggaran, keterbukaan terhadap hasil spending review, pendekatan yang digunakan dalam mengimplementasikan spending review, penyampaian laporan dan dampak hasil review, Keempat, faktor waktu yang mempengaruhi spending review.

Faktor pendorong pengintegrasian spending review adalah sebagai berikut:

1. Dimensi Sosial Berupa dukungan organisasi non Pemerintah dan organisasi Internasional

Inisiasi awal implemetasi spending review Kementerian Keuangan bisa ditelusuri dari keterlibatan perwakilan DJPb dalam konferensi Organisation for Economic Co-operation and Development (OECD) pada tahun 2011. Pengaruh dari OECD, baik pemaparan dalam konferensi maupun dari konsep, teori dan ide yang tertuang dalam OECD Journal On Budgeting kemudian menjadi landasan konsep awal pengintegrasian spending review dalam siklus penganggaran Indonesia.

NGO lainnya yang aktif mendukung Kementerian Keuangan dalam implementasi spending review adalah Program Kemitraan Australia Indonesia untuk Perekonomian (Prospera). Prospera secara intensif membantu Kementerian Keuangan terkait penyusunan 
metodologi spending review. Australia telah berpengalaman dalam mengimplementasikan reformasi manajemen keuangan dalam wujud kegiatan Program Perbaikan Pengelolaan Keuangan untuk menguatkan kaitan antara anggaran dan outputnya. Keberhasilan Australia dalam mengaitkan spending review ke dalam siklus anggaran adalah dengan memasukkan informasi kinerja (hasil dan keluaran) ke dalam dokumen penganggaran, yaitu berupa rancangan anggaran, portofolio pernyataan anggaran dan laporan keuangan tahunan (Bouckaert \& Halligan, 2008).

Lembaga Internasional Non Pemerintah lainnya yang menjadi faktor pendorong penerapan spending review adalah Bank Dunia. Bank Dunia dalam beberapa kesempatan memberikan masukan beberapa hal terkait pengelolaan keuangan publik (public financial management) di Indonesia yang dapat digunakan untuk penyempurnaan metodologi spending review. Bank Dunia (2016) telah membuat kajian terkait kualitas belanja APBN Indonesia, namun lebih fokus pada pengukuran kualitas belanja dari sisi efisiensi alokasi yang terfokus pada pengukuran keluaran anggaran agregat. Studi Bank Dunia pada 2016 mengenai kinerja operasional berupa efisiensi teknis belanja di Indonesia hanya mengambil sektor pendidikan sebagai objek kajian dan tidak bersifat komprehensif lintas tahun (World Bank, 2016).

2. Dimensi Organisasi berupa koordinasi intern dan antar Instansi serta dukungan Kementerian Keuangan

Pada tahap awal pelaksanaan spending review yaitu pada tahun 2013, perspektif kualitas belanja belum berkembang sebagaimana pada tahun 2019. Pemahaman kualitas belanja yang lazim dianut oleh pihak internal Direktorat Jenderal Perbendaharan (DJPb) dan Kementerian/Lembaga masih menitikberatkan pada kelancaran penyaluran belanja dan perbandingan antara realisasi belanja dengan anggaran yang telah dialokasikan. Perspektif tersebut menyebabkan dukungan terhadap spending review belum cukup tinggi. Hal itu mendorong $\mathrm{DJPb}$ melakukan sosialisasi dan penguatan internalisasi program kerja untuk melakukan manajemen perubahan guna meningkatkan kualitas belanja. Berbagai kegiatan tersebut berpengaruh terhadap perubahan perspektif banyak pihak untuk melihat pentingnya reviu belanja secara menyeluruh. Hingga saat ini dukungan untuk penguatan implementasi spending review di internal $\mathrm{DJPb}$ telah meningkat pesat dan menjadi salah satu faktor pendorong pengintegrasian spending review.

Selain internal DJPb, Direktorat Jenderal Anggaran (DJA) adalah instansi selanjutnya yang memiliki tugas dan fungsi yang salah satunya untuk meningkatkan kualitas belanja Kementerian/Lembaga. Spending review memiliki hubungan erat dengan dampak yang 
ditimbulkan dari adanya pengalokasian anggaran yang merupakan tugas dan fungsi DJA. Dampak anggaran tersebut dapat dikaji berdasarkan konsep nilai uang yaitu pengukuran implementasi teori 3E, yaitu ekonomis, efisiensi, dan efektivitas.

Sejak awal implementasi spending review diinisiasi oleh DJPb, DJA sangat mendukung karena DJA membutuhkan analisa tersebut sebagai bahan pertimbangan dalam pengalokasian anggaran. DJA berperan di posisi hulu dalam siklus penganggaran sementara $\mathrm{DJPb}$ berperan dalam pelaksanaan dan pertanggungjawaban anggaran di posisi hilir dalam siklus penganggaran. Dengan semakin meningkatnya koordinasi antara DJPb dan DJA, pemenuhan kebutuhan pelaksanaan tugas masing-masing dapat semakin selaras, serta meningkatkan kualitas siklus anggaran dari hulu ke hilir. Dengan adanya dukungan yang besar dari DJA, pelaksanaan spending review di DJPb dapat diimplementasikan dengan baik. Meskipun spending review pada saat ini belum dilakukan oleh Kementerian Kesehatan, namun dukungan dari Kementerian Keuangan terutama DJPb dan DJA sangat vital terutama dalam mengembangkan metodologi yang sesuai dan menjadi acuan dalam pra implementasinya.

Peningkatan koordinasi antar unit lingkup Kementerian Kesehatan memungkinkan penyelarasan sistem dan mekanisme sehingga memudahkan pelaksanaan reviu. Tanpa keterlibatan aktif otoritas penganggaran pada kementerian, akan menjadi faktor penghambat utama pencapaian tujuan dari penyusunan spending review. Tantangan utama dalam pengukuran efisiensi teknis spending review adalah penentuan informasi kinerja yang relevan dan valid berupa masukan, keluaran dan hasil yang tertuang dalam dokumen perencanaan dan penganggaran. Oleh karena itu, diperlukan adanya koordinasi yang baik terutama ketika terjadi revisi masukan, keluaran dan hasil pada kegiatan Kementerian Kesehatan yang akan direviu.

Koordinasi Internal Kementerian Kesehatan terkait informasi kinerja yang berkualitas telah diupayakan untuk semakin meningkat dari tahun ke tahun. Pada level Kementerian Keuangan telah dikembangkan aplikasi eRekon\&LK bagi satuan kerja, sehingga ketika melakukan rekonsiliasi laporan keuangan, sekaligus melaporkan informasi kinerjanya yang terkait. Implementasi di lapangan pada awal tahun 2020, masih ditemukan adanya data informasi kinerja yang belum akurat, sehingga Kementerian Keuangan melakukan pemutakhiran dan penyempurnaan data informasi kinerja untuk Tahun Anggaran 2019.

3. Dimensi Proses berupa Metodologi/Prosedur Operasi Standar

Metodologi teknis pelaksanaan spending review yang diimplementasikan pada negara lain, belum tentu sesuai bila akan dilaksanakan di Indonesia. Kementerian Keuangan dalam 
hal ini $\mathrm{DJPb}$ telah mengembangkan sendiri metodologi atau proses yang menyesuaikan dengan sistem perencanaan dan penganggaran di Indonesia, sehingga hal ini dapat menjadi faktor pendorong keberhasilan spending review. Bagaimanapun juga dampak belanja yang baik adalah dampak yang sesuai dengan harapan yang dituangkan dalam dokumen perencanaan pemerintah.

SOP dalam pelaksanaan spending review telah dirumuskan oleh Kementerian Keuangan dalam hal ini Direktorat Jenderal Perbendaharaan dan secara periodik disempurnakan sejak tahun 2013 dengan menerbitkan surat edaran penyusunan spending review yaitu berupa SE-54/PB/2013 tentang Petunjuk Teknis Pelaksanaan dan Penyusunan Spending Review tahun 2013, SE-02/PB/2015 tentang Penyusunan Spending Review tahun 2015, SE-12/PB/2016 tentang Penyusunan Spending Review, dan terakhir dalam SE107/PB/2018 tentang Pelaksanaan Spending Review dan Laporan Spending Review Tahun 2018. Surat edaran tersebut masih bersifat internal dan hanya diberlakukan untuk organisasi di wilayah kerjanya dalam hal ini di tingkat pusat pelaksanaan spending review dilakukan oleh Direktorat Pelaksanaan Anggaran, dan di tingkat daerah yang dilakukan oleh Kanwil Direktorat Jenderal Perbendaharaan. Pelaksanaan spending review tersebut kemudian dipayungi oleh peraturan perundang-undangan berupa Peraturan Menteri Keuangan Nomor PMK-195/PMK.05/2018 tentang Monitoring dan Evaluasi Pelaksanaan Anggaran.

Spending review dilakukan dengan metodologi sebagai berikut:

1. Melihat sasaran dan target pembangunan yang telah ditetapkan dalam RPJMN, RKP dan sasaran belanja tahunan.

2. Mengkaitkan alokasi belanja dengan tujuan dan sasaran yang telah di tetapkan.

3. Reviu atas eksekusi belanja, atas alokasi belanja yang menjadi kegiatan strategis Pemerintah baik dari sisi capaian realisasi dan progresnya serta beberapa perubahan yang dilakukan terhadap alokasi anggaran tersebut di sepanjang tahun anggaran.

4. Identifikasi berbagai hambatan yang di hadapi dan perkembangan penyelesaiannya sehingga dapat menjadi uman balik untuk mitigasi risiko periode selanjutnya

Saat ini jenis reviu yang dilaksanakan oleh DJPb masih berupa reviu fungsional atau dikenal dengan reviu efisiensi (Robinson, 2013). Review efisiensi berfokus pada kesesuaian antara masukan dengan ketercapaian keluaran. Di mana hasil dari review akan memperlihatkan tingkat inefisiensi belanja dari suatu K/L. Spending Review DJPb yang saat ini hanya melakukan review efisiensi bukan tidak mungkin dapat berkembang menjadi reviu strategis. Reviu strategis adalah kegiatan pemprioritasan strategis dengan metode penghematan yang memungkinkan pemerintah mengurangi alokasi atau bahkan menghapus 
keseluruhan anggaran suatu program atau kegiatan karena dibuktikan tidak efektif, kemudian hasil dari penghematan tersebut digunakan pemerintah untuk menambah porsi anggaran program lainnya yang dapat dibuktikan lebih efektif memberi manfaat bagi masyarakat (Pollitt \& Bouckaert,2014). Lebih jauh, reviu strategis memunculkan adanya kemungkinan suatu unit organisasi kehilangan eksistensinya bila melalui proses reviu strategis ditemukan fakta bahwa suatu organisasi ternyata tidak dapat memberikan hasil sebagaimana diharapkan. Dasar teorinya adalah sebuah unit organisasi yang tidak memberikan kontribusi atau hasil yang optimal kepada masyarakat ketika berdiri sendiri, sebaiknya tidak perlu ada daripada hanya menambah beban keuangan negara, sehingga perlu direformasi dengan dilebur atau paling tidak dilikuidasi dengan K/L lainnya. Hal tersebut terjadi karena setiap unit satuan kerja pada $\mathrm{K} / \mathrm{L}$ yang dibentuk dalam sistem pada dasarnya diharapkan harus memproduksi barang/jasa yang sesuai kebutuhan masyarakat. Bila berdasarkan hasil reviu strategis barang/jasa yang dihasilkan tidak dibutukan masyarakat, maka satker tersebut tidak memiliki kegunaan, sehingga dapat dilakukan penghapusan maupun peleburan satker. Namun hal tersebut akan sulit terjadi terhadap satuan kerja yang memiliki banyak agenda prioritas nasional seperti Kementerian Kesehatan.

Sedangkan factor-faktor penghambat pengintegrasian spending review adalah sebagai berikut:

1. Dimensi Sosial berupa dukungan Publik

Pelaksanaan spending review belum disampaikan kepada publik dengan beberapa pertimbangan. Namun keterlibatan publik akan didorong dengan penyampaian hasil review kepada publik dengan tetap memberikan batasan mana yang dapat disajikan secara umum kepada publik dan yang secara intensif disampaikan kepada K/L. Publik sebagai penerima jasa/barang yang diproduksi oleh pemerintah berperan besar dalam menentukan bagaimana seharusnya spending review memberikan dampak peningkatan layanan K/L yang lebih baik.

Belum terdapat bukti yang jelas maupun penelitian bahwa spending review telah memperbaiki kualitas output (pelayanan) Pemerintah kepada masyarakat. Peningkatan kinerja yang terjadi pada beberapa K/L sulit untuk dapat dikatakan sebagai akibat langsung dari pengintegrasian spending review dikarenakan terbatasnya pengaruh spending review terhadap output satker pada K/L serta hasil spending review yang belum sepenuhnya dipergunakan untuk pengambilan keputusan anggaran. Para peneliti dan civitas akademik dapat turut membantu mendorong perubahan perspektif kualitas belanja yang lebih baik melalui pembuatan kajian optimalisasi pengintegrasian spending review. 
2. Dimensi Organisasi

a. Kualitas Data Penganggaran

Analisa spending review membutuhkan berbagai sumber daya baik di sisi SDM, fasilitas, dan sistem yang mendukung. Sumber data atau dokumen sumber untuk melakukan analisa spending review terutama berasal dari dokumen perencanaan dan penganggaran yang disebut dengan Rencana Kerja dan Anggaran Kementerian/Lembaga (RKA K/L). RKA K/L menampilkan data antara program, kegiatan, alokasi anggaran serta output yang diharapkan. Namun demikian, informasi indikator kinerja yang disajikan dalam RKA K/L masih terbatas, padahal proses penyusunan spending review sangat dipengaruhi oleh kualitas data yang tertuang dalam RKA K/L sebagai dokumen sumber utama.

Masih dapat ditemukan bahwa output yang disajikan dalam RKA K/L bukanlah merupakan output yang benar-benar dihasilkan dari kegiatan yang dilakukan serta anggaran yang dialokasikan. Permasalahan selanjutnya adalah belum terdapat definisi yang jelas terkait dengan output yang didefinisikan oleh Bappenas serta kurangnya panduan dan pembinaan kepada K/L. Terbatasnya kualitas informasi output tersebut juga telah diidentifikasi oleh Direktorat Sistem Penganggaran RKA K/L. Penganggaran berbasis kinerja telah diimplementasikan sejak tahun 2005 dan pemerintah telah berusaha menyajikan keterkaitan antara masukan, keluaran dan hasil; akan tetapi berdasarkan evaluasi terhadap kinerja program K/L, terdapat temuan terkait kualitas keluaran yang masih perlu disempurnakan. Belum jelas dan validnya $\mathrm{K} / \mathrm{L}$ dalam mengidentifikasi masukan, keluaran dan hasil nya memberikan hambatan terhadap pengintegrasian spending review.

Kementerian Keuangan telah melakukan upaya perbaikan untuk memperbaiki permasalahan dimaksud. Kementerian Keuangan telah mengupayakan penataan Arsitektur dan Informasi Kinerja (ADIK) yang bertujuan untuk melakukan sinkronisasi antara inputoutput-outcome dan penggunaan aplikasi Sistem Perbendaharaan dan Anggaran Negara (SPAN). Penyempurnaan dimaksud antara lain ditargetkan untuk meningkatkan kualitas rumusan kinerja dan meningkatkan keterkaitan antara indikator kinerja (input, output dan outcome). Aplikasi SPAN melakukan validasi terhadap data yang disajikan oleh $\mathrm{K} / \mathrm{L}$ kemudian bila terdapat data yang tidak sesuai dengan kaidah-kaidah Sistem Perbendaharaan dan Anggaran Negara, RKA-K/L dikembalikan kepada Kementerian/Lembaga untuk dilakukan perbaikan. Selanjutnya atas realisasi capaian output, Kementerian Keuangan telah membangun Sistem Aplikasi Keuangan Tingkat Instansi (SAKTI) dan Electronic Rekonsiliasi Laporan Keuangan (e Rekon LK). Pada tataran implementasi masih ditemukan adanya satuan kerja yang belum secara akurat melaporkan capaian outputnya, sehingga masih 
diperlukan konfirmasi secara manual, untuk menghindari adanya hasil analisa spending review yang salah akibat ketidakakuratan data. Sebaik apapun sistem, bila data yang masuk kurang berkualitas, maka akan menghasilkan keluaran data yang kurang berkualitas juga. Sistem spending review juga diindikasikan masih memiliki banyak celah untuk perbaikan, dikarenakan adanya penyempurnaan terus menerus baik metode penelaahan DJA maupun metode spending review $\mathrm{DJPb}$. Perkembangan kebutuhan sistem TI tersebut menjadi permasalahan tersendiri bagi $\mathrm{DJPb}$.

\section{b. Persepsi Kementerian/Lembaga Terhadap Hasil Spending Review}

Hasil spending review menunjukkan kegiatan-kegiatan K/L yang belum menghasilkan output maupun outcome dengan optimal sehingga menimbulkan resistensi atas hasil reviu yang dilakukan. Persepsi K/L secara signifikan mempengaruhi efektivitas kegiatan reviu atas belanjanya.

c. SDM Kementerian Kesehatan

Kualitas dan jumlah pegawai yang memiliki kualifikasi untuk melakukan reviu pada masing-masing $\mathrm{K} / \mathrm{L}$ dapat menjadi faktor penghambat pelaksanaan spending review. SDM yang dimiliki masing-masing satker K/L adalah SDM yang umumnya memiliki kompetensi teknis dibidang K/L masing-masing, namun memiliki keterbatasan kompetensi dibidang pengelolaan keuangan. Hal tersebut pun terjadi pada Kementerian Kesehatan dimana SDM yang dimilikinya tidak memiliki kemampuan kompetensi yang seragam, sehingga diperlukan usaha lebih untuk meningkatkan SDM tersebut agar memiliki kemampuannya yang sama. Bilamana dilihat dari struktur organisasi Inspektorat Jenderal Kementerian Kesehatan, pejabat Itjen masih didominasi oleh pejabat yang latar belakang pendidikannya adalah bidang selain akuntansi. Latar belakang pendidikan auditor memiliki pengaruh besar terhadap kualitas hasil audit, dimana pendidikan formal akuntansi, utamanya auditing merupakan kemampuan kompetensi teknis utama yang vital dimiliki seorang auditor.

Tidak hanya permasalahan kualitas, namun jumlah SDM pada Kementerian Kesehatan juga disimpulkan masih terbatas. Masih terdapat banyak rangkap jabatan antara pejabat struktural dan pengelola keuangan. Permasalahan SDM pengelolaan keuangan menjadi sorotan BPK dalam Laporan Hasil Pemeriksaan (LHP) atas Laporan Keuangan dengan merekomendasikan pejabat eselon I agar menginstruksikan kepala satker terkait untuk menegur para pengelola keuangannya seperti bendahara, pejabat pembuat komitmen, pejabat pengadaan barang dan jasa, pejabat penandatangan surat pemerintah membayar serta pengelola keuangan lainnya atas kelalaian dalam pengelolaan keuangan K/L masing-masing. 
ARTIKEL

Untuk mengatasi permasalahan kualitas SDM, Kementerian Keuangan telah berinisiatif menyelenggarakan pelatihan yang memiliki hubungan dengan spending review dan telah mulai dilakukan sejak tahun 2013. Pendidikan dan pelatihan yang telah diselenggarakan antara lain berupa Pelatihan Reviu Anggaran, diklat reviu RKA K/L, diklat penelaahan RKA K/L, lokakarya spending review untuk biaya overhead, serta diklat reviu proposal anggaran. Namun demikian, peserta diklat tersebut sebagian besar masih didominasi oleh pegawai Kementerian Keuangan.

\section{d. Proses Transfer Pengetahuan}

Kementerian Keuangan, dalam ha ini DJPb memiliki kualitas pegawai yang baik, sehingga mampu mendukung pelaksanaan spending review. Namun sumber daya manusia tersebut masih perlu dibekali kemampuan teknis pelaksanaan spending review melalui pendidikan dan pelatihan. Kebutuhan transfer pengetahuan kepada para pegawai DJPb dalam persiapan pelaksanaan review membutuhkan waktu pembelajaran khusus, sehingga DJPb bekerjasama dengan BPPK melakukan pembagian waktu penyelesaian spending review secara tepat dan melakukan transfer pengetahuan secara bertahap. Pendidikan dan pelatihan tersebut sejauh ini dapat dilakukan dengan cukup baik, walaupun memerlukan waktu/proses dan usaha yang lebih besar. Untuk mengatasi hal tersebut, telah diusahakan transfer pengetahuan secara terpecah, atau sedikit demi sedikit sehingga dapat dilakukan bersamaan dengan pelaksanaan pekerjaan lain.

Kebaharuan spending review, serta variabilitas dan perubahan/revisi prioritas belanja pada masing-masing $\mathrm{K} / \mathrm{L}$ menyebabkan perlunya adanya transfer pengetahuan secara terus menerus kepada pelaksana di lapangan. Hal itulah yang menyebabkan transfer pengetahuan pada saat ini belum maksimal sehingga menyebabkan review yang dilakukan di masingmasing K/L mempunyai celah kekurangan sehingga memerlukan tambahan waktu atau tambahan SDM untuk menghasilkan reviu yang berkualitas.

Proses dan mekanisme pelaksanaan spending review belum banyak diketahui oleh K/L, khususnya Kementerian Kesehatan. Itjen Kementerian Kesehatan yang merupakan salah satu bagian dari K/L yang melaksanakan review atas anggaran pun masih asing dengan proses spending review.

3. Dimensi Proses

a. Peraturan Perundangan

Faktor peraturan menjadi salah satu penghambat integrasi spending review dalam pengambilan keputusan anggaran Kementerian/Lembaga. Pasal 10 ayat (4) PMK Nomor 195/PMK.05/2018 Tentang Monitoring dan Evaluasi Pelaksanaan Anggaran Belanja 
Kementerian Negara/Lembaga menetapkan bahwa Laporan reviu belanja berupa spending review tingkat nasional disampaikan kepada Direktur Jenderal Perbendaharaan, Direktur Jenderal Anggaran, dan Menteri Keuangan dalam rangka perbaikan kebijakan di bidang penganggaran. Berdasarkan ketentuan tersebut maka tidak ada keharusan bagi Kementerian Keuangan untuk menyampaikan Laporan Spending Review kepada Kementerian/Lembaga untuk dimanfaatkan sebagai acuan dalam pengambilan keputusan anggaran Kementerian/Lembaga yang bersangkutan.

Kelemahan dalam peraturan tersebut adalah sifat spending review yang saat ini hanya sebagai penyampaian informasi yang sifatnya tidak mengikat kepada K/L. Seharusnya kedepan bersifat mengikat dalam rangka pengambilan keputusan K/L.

b. Keterlibatan Kementerian dalam Pelaksanaan Spending Review

Penyusunan spending review K/L dilakukan oleh Kementerian Keuangan (DJPb) yang kemudian hasilnya dikonfirmasi kepada K/L masing-masing, yang tidak lain merupakan pendekatan atas-bawah. Reviu atas bawah adalah spending review dimana pilihan penghematan dikembangkan oleh Menteri Bidang Keuangan/Perbendaharaan dengan keterlibatan Kementerian selaku pengguna anggaran yang terbatas. KL tidak melakukan spending review atas dirinya sendiri secara mandiri, melainkan melakukan reviu anggaran dalam bentuk evaluasi anggaran. Keterlibatan $\mathrm{K} / \mathrm{L}$ dalam penyusunan spending review Kementerian Keuangan hanya sebatas konfirmasi hasil spending review dimaksud. Sedangkan pengembangan metodologi dan implementasi spending review dalam wujud identifikasi tingkat efisiensi operasional dilakukan oleh DJPb, Kementerian Keuangan. Spending review yang dilakukan oleh $\mathrm{DJPb}$ dikonfirmasi ke $\mathrm{K} / \mathrm{L}$ secara rutin dengan mengundang Biro/Bagian Perencanaan, Biro/Bagian Keuangan, APIP, bersama beberapa perwakilan $\mathrm{K} / \mathrm{L}$ yang dianggap penting untuk menyampaikan indikasi temuan hasil spending review. Perwakilan K/L tersebut berhak memberikan tanggapan bilamana tidak sependapat dengan hasil spending review. Pendekatan atas-bawah yang digunakan dalam implementasi spending review Indonesia mengakibatkan terhambatnya peningkatan pengintegrasian spending review. Dampak dari hambatan tersebut dapat dilihat dari dari lambatnya pengembangan metodologi, kualitas hasil spending review, serta tingkat pemanfaatan atas hasil temuan dalam proses penganggaran.

c. Penyampaian Laporan dan Dampak Hasil Spending Review pada Kementerian Kesehatan

Spending review yang dilakukan oleh Kementerian Keuangan terhadap Anggaran K/L terdiri dari analisa yang beragam, mulai dari reviu pagu, reviu alokasi, hingga reviu atas reviu 
yang dilakukan inspektorat. Hasil dari spending reviu belum optimal digunakan $\mathrm{K} / \mathrm{L}$ dan seolah-olah berdiri sendiri dari reviu lainnya, sehingga BPK masih menemukan temuan terkait belanja setiap tahun, kemudian ditemukan adanya einmalig, serta inefisiensi belanja. Hasil penelitian menunjukkan bahwa tidak semua unit yang berkepentingan di K/L menerima laporan spending review yang telah dibuat Kementerian Keuangan. Hasil penelitian juga menyimpulkan bahwa pemanfaatan atas hasil spending review juga masih sangat minimal bahkan diabaikan

\section{Dimensi Waktu}

Peneliti menyimpulkan bahwa penyusunan spending review dapat terhambat karena keterbatasan waktu. Pada saat melakukan review RKA K/L, responden banyak mengeluhkan kurangnya alokasi waktu, apalagi jika akan ditambah kegiatan spending review. Adanya pembatasan hal-hal yang dilakukan terkait anggaran erat kaitannya dengan alokasi waktu dalam proses penganggaran tahunan. Keterbatasan waktu tersebut memberikan dampak terhadap kualitas dokumen RKA K/L yang tidak optimal sehingga pada akhirnya selalu ditemukan kekurangan baik oleh pemeriksa maupun pada hasil spending reviu. Kementerian Kesehatan pada saat ini telah melakukan reviu RKA K/L.

Spending review yang dilakukan oleh Kementerian Keuangan terhadap Anggaran K/L terdiri dari analisa yang beragam, mulai dari reviu pagu, reviu alokasi, hingga reviu atas reviu yang dilakukan inspektorat sehingga dibutuhkan kerangka waktu yang tepat atas kegiatan tersebut. Reviu terhadap RKA K/L terlihat dilakukan secara bertingkat dan berulang namun belum memberikan dampak optimal dan digunakan masing-masing $\mathrm{K} / \mathrm{L}$ serta seolah-olah tidak terintegrasi antara reviu satu dengan lainnya. Hal tersebut disebabkan keterbatasan waktu yang dimiliki. Kerangka waktu yang baik dapat memberikan kesempatan bagi APIP untuk melakukan pendalaman terhadap reviu yang dilakukan serta menjaga kesesuaian dengan peraturan yang berlaku.

Praktek reviu yang saat ini telah dilakukan baik oleh Biro Perencanaan dan Penganggaran dan Itjen Kementerian Kesehatan lebih ke arah penelaahan dan ketaatan terhadap peraturan sehingga tidak membutuhkan analisa yang mendalam dan waktu yang tidak terlalu lama. Hal ini berbeda dengan konsep spending review yang menganalisa hubungan antara indikator input dan indikator output dengan seksama dan menggunakan berbagai metode. 


\section{KESIMPULAN}

Faktor-faktor pendukung pengintegrasian spending review dalam pengambilan keputusan anggaran pada Kementerian Kesehatan antara lain: 1) Dimensi Sosial berupa dukungan organisasi Non Pemerintah dan Organisasi Internasional seperti Bank Dunia; 2) Dimensi organisasi berupa koordinasi internal dan antar instansi yang berjalan dengan baik, serta dukungan Kementerian Keuangan dan Kementerian Kesehatan terhadap pelaksanaan spending review; 3) Dimensi proses berupa metodologi atau standar prosedur operasi mengenai spending review telah dimiliki oleh Kementerian Keuangan.

Faktor-faktor penghambat pengintegrasian spending review dalam pengambilan keputusan anggaran pada Kementerian Kesehatan antara lain: 1) Dimensi sosial berupa belum adanya dukungan publik karena spending review belum diketahui oleh publik. 2) Dimensi organisasi berupa data penganggaran yang kurang berkualitas, Kementeian/Lembaga kemungkinan memiliki persepsi yang kurang baik terhadap spending review karena dianggap mencari kesalahan Kementerian/Lembaga, kapasitas sumber daya manusia yang masih perlu ditingkatkan untuk melaksanakan spending review serta masih diperlukan transfer pengetahuan dari Kementerian Keuangan kepada Kementerian Kesehatan mengenai spending review. 3) Dimensi proses berupa peraturan perundang-undangan yang membatasi distribusi laporan spending review hanya untuk internal Kementerian Keuangan, Kementerian Kesehatan belum dilibatkan dalam pelaksanaan spending review serta Kementerian Kesehatan tidak menerima laporan spending review sehingga tidak mengetahui rekomendasi perbaikan yang perlu ditindaklanjuti oleh Kementerian Kesehatan. 4) Dimensi waktu berupa keterbatasan waktu pelaksanaan reviu pada Kementerian Kesehatan.

\section{DAFTAR PUSTAKA}

Cassell, C., Cunliffe, A. L., \& Grandy, G. (Eds.). (2017). The SAGE Handbook of Qualitative Business and Management Research Methods. London: Sage.

Catalano, G., \& Erbacci, A. (2018). A Theoretical Framework for Spending Review Policies at a Time of Widespread Recession. OECD Journal on Budgeting, 17(2), 9-24.

Hawkesworth, I., \& Klepsvik, K. (2013). Budgeting Levers, Strategic Agility and the Use of Performance Budgeting in 2011/12. OECD Journal on Budgeting, 13(1), 105-140.

Irvin, R. A., \& Stansbury, J. (2004). Citizen participation in decision making: is it worth the effort? Public Administration Review, 64(1), 55-65.

Melkers, J. E., \& Willoughby, K. G. (2001). Budgeters' views of state performancebudgeting systems: Distinctions across branches. Public Administration Review, 61(1), 54-64. 
OECD. (2011). Typology and Implementation of Spending Reviews. OECD SBO Meeting on Performance and Results, November, 2011.

Parhusip, B. (2016). Analisis Implementasi Spending Review pada Kementerian Negara/Lembaga Tahun 2013-2015. Kajian Ekonomi dan Keuangan, 20(3), 191-211.

Pollitt, C., \& Bouckaert, G. (2017). Public Management Reform: A Comparative Analysisinto the Age of Austerity. New York: Oxford University Press.

Postuła, M. (2017). Spending Reviews-a Tool to Support the Efficient Management of Public Funds. Journal of Management and Business Administration, 25(2), 63-90.

Prabowo, C. E. (2018). Spending Review 2018: Meningkatkan Value for Money Belanja Pemerintah. Indonesian Treasury Update, 3(2), 30-42.

Robinson, S. E. (2003). Bureaucrats and public schools: Does bureaucratization promote incrementalism in program budgeting for Texas school? The University of Texas at Dallas Political Economy Working Paper, Richardson, Texas.

Robinson, M. (2013). Spending Review. Working Party of Senior Budget Officials. 3'th Annual Meeting of OECD Senior Budget Officials, OECD Conference Centre, Paris, 3-4 June, 1-9.

Rutgers, M. R., \& Van Der Meer, H. (2010). The Origins and Restriction of Efficiency in Public Administration: Regaining Efficiency as the Core Value of Public Administration. Administration \& Society, 42(7), 755-779.

Simon, H. A. (1959). Theories of decision-making in economics and behavioral science. The American Economic Review, 49(3), 253-283.

Thurmaier, K. (1992). Budgetary decisionmaking in central budget bureaus: An experiment. Journal of Public Administration Research and Theory, 2(4), 463-487.

Thurmaier, K. (1995a). Execution Phase Budgeting in Local Governments: It's not just for control anymore! State \& Local Government Review, 27(2), 102-117.

Thurmaier, K. M., \& Willoughby, K. G. (2001). Policy and Politics in State Budgeting. New York: M. E. Sharpe.

Van Dooren, W., Bouckaert, G., \& Halligan, J. (2015). Performance Management in the Public Sector. New York: Routledge.

World Bank (2013) Beyond the Annual Budget: Global Experience with Medium-Term Expenditure Frameworks. Washington, D.C: World Bank.

Yin, Robert K. (2014). Case Study Research Design and Methods: Applied Social Research Methods Series (5th ed.). Thousand Oaks. 